\title{
ANALISIS RENCANA STRATEGIS PEMERINTAH KABUPATEN BANYUWANGI DALAM PENANGGULANGAN BENCANA ALAM
}

\author{
Burhanudin Mukhamad Faturahman \\ Pusat Penelitian Badan Keahlian DPR RI \\ Email: burhanmfatur@gmail.com
}

\begin{abstract}
Strategic plan is series of stages rational thought to produce an effective strategy. The purpose to know strategy of Banyuwangi Regency Government in response natural disasters through strategic plan (Renstra). Research Methods use qualitative descriptive approach and data analysis use content analysis to analyze document of regional disaster Management Agency (BPBD) Banyuwangi Regency Year 20192021 use Vision of Success Approach from Bryson. The results show that the vision of the National Medium-Term Development is used as a reference for Banyuwangi Regency BPBD Strategic Plan in dealing with natural disasters at local level. This is also supported by the vision of selected regional heads who are committed to providing public services including disaster services on aspects of natural disaster risk reduction and optimization of natural disaster emergency response management. In addition, strategies to manage disaster issues are optimizing organizational management and strengthening the tasks and functions of disaster management comprehensively. However, the process of strategic planning stages there is still no systematic schedule and communication still relies on disaster information from the Meteorology and Geophysics Agency. BPBD Strategic Plan is local governments guideline to take disaster policies so that the documents compiled by BPBD must be complete and comprehensive
\end{abstract}

Article Histori: Submited: 08/11/2019

Editing: 28/04/2020

Publish: $30 / 4 / 2020$

Keyword: Strategic Plan, Natural Disaster, Local Goverment

\section{PENDAHULUAN}

Negara Kesatuan Republik Indonesia disamping memiliki sumberdaya alam yang melimpah juga memiliki potensi bencana alam yang tidak bisa dipandang sebelah mata. Letak geologis menempatkan Indonesia pada jalur lingkar gunung berapi dunia serta terletak pada lempeng benua (Benua Asia, Benua Australia, lempeng Samudera Hindia dan Samudera Pasifik) menyebabkan rawan terkena dampak letusan gunung berapi dan gempa bumi. Dari sisi demografis dan geografis dengan sebagian besar kepualauan, turut 
menambah tingkat kerawanan terhadap bencana alam dikarenakan jumlah populasi mencapai 260 juta jiwa yang tersebar di pegunungan dan pesisir pantai. Kondisi tersebut menyebabkan kerawanan penduduk yang terkena dampak bencana seperti letusan gunung berapi, gempa bumi, tsunami, tanah longsor) dan banjir. Salah satu bukti konsekuensi dari letak geologis menjadikan Indonesia sebagai salah satu negara yang memiliki tingkat kegempaan yang tinggi di dunia, lebih dari 10 kali lipat tingkat kegempaan di Amerika Serikat (BNPB, 2017).
Jumlah peristiwa bencana menunjukkan insentisas yang cenderung meningkat sebagaimana menurut data dari Data Informasi Bencana Indonesi (DIBI) BNPB, telah terjadi dari lebih dari 1.800 kejadian bencana pada periode tahun 2005-2015 lebih dari $78 \%$ (11.648) yaitu bencana hidrometeorologi berupa berupa kejadian bencana banjir, gelombang ekstrim, kebakaran lahan dan hutan, kekeringan, dan cuaca esktrim dan hanya sekitar 22\% (3.810) merupakan bencana geologi berupa gempabumi, tsunami, letusan gunungapi, dan tanah longsor.

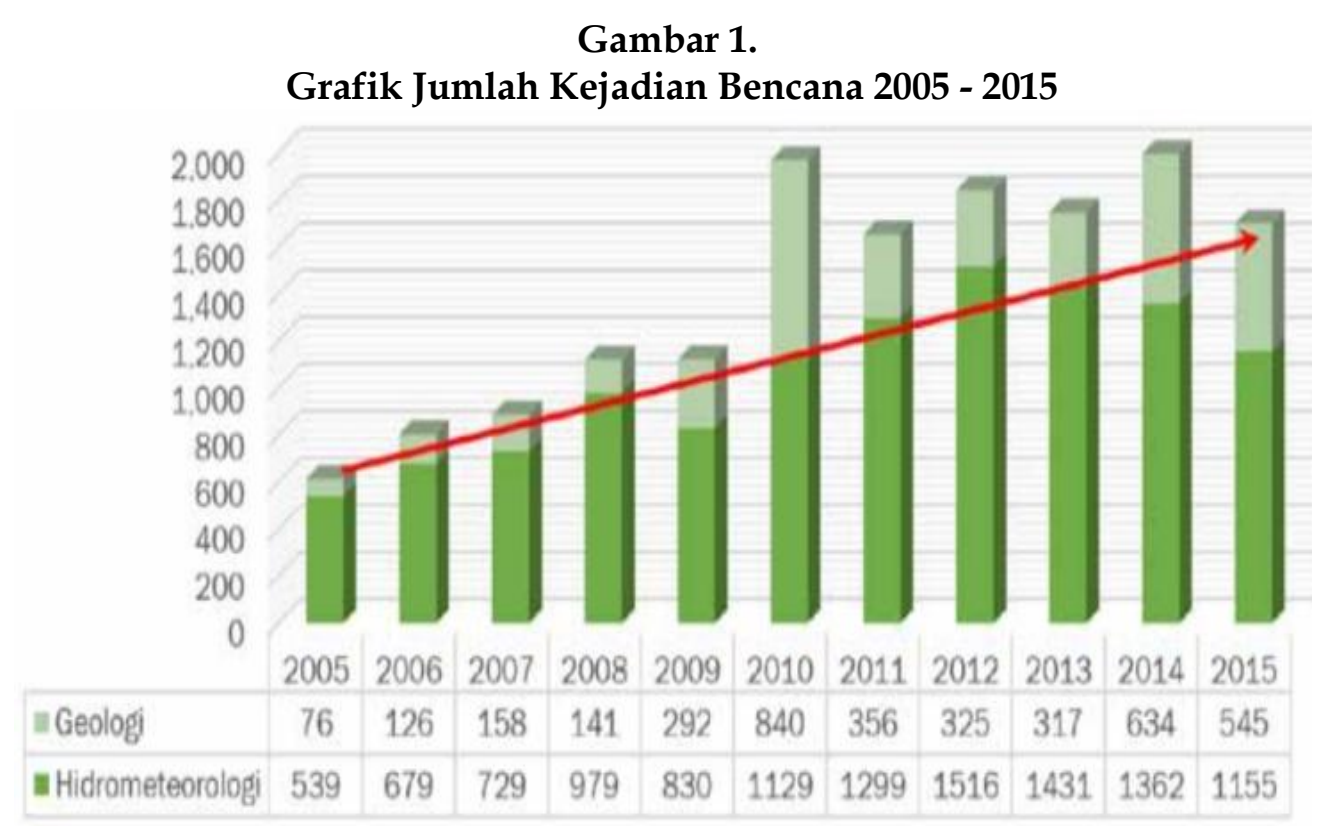

Sumber: BNPB, 2016

Data pada gambar 1 tersebut menunjukkan fluktuasi intensitas bencana alam namun secara keseluruhan menunjukkan tren yang meningkat. Beragamnya bencana alam yang pernah terjadi di berbagai wilayah di Indonesia membuat risiko bahaya juga beragam sesuai karakteristik daerah bencana. Berdasarkan hasil kajian risiko bencana di Indonesia tahun 2015, total potensi jiwa terpapar bencana (sedang-tinggi) lebih dari 255 juta jiwa, nilai aset terpapar lebih dari Rp. 650 triliun dan nilai ekonomi terpapar lebih dari
Rp. 480 Triliun. Provinsi Jawa Barat menempati urutan pertama yaitu memiliki risiko bencana 46 juta jiwa, fisik 68 triliun, ekonomi 43 triliun dan lingkungan 262 ribu hektar. Urutan kedua yaitu Provinsi Jawa Timur sebesar 38 juta jiwa, fisik 52 triliun, ekonomi 48 triliun dan lingkungan 442 ribu hektar. Urutan ketiga yaitu Provinsi Jawa Tengah sebesar 32 juta jiwa, fisik 53 triliun, ekonomi 56 triliun dan lingkungan 101 ribu hektar (BNPB,2016).

Salah satu kabupaten di Provinsi Jawa Timur yang rawan terhadap ancaman 
bencana alam adalah Kabupaten Banyuwangi dengan potensi kerawanan bencana tsunami, bencana gunung berapi, puting beliung, tanah longsor, kekeringan maupun bencana kebakaran. Pada pertengahan tahun 2018, peristiwa banjir bandang terjadi di Banyuwangi dikarenakan jebolnya tanggul alami serta tanah longsor di hulu dengan perincian 1.721 hektar lahan pertanian rusak dan 328 rumah (Pramono dan savitri, 2018) sedangkan kerugian tersebut mencapai Rp. 5 miliar (Saksono, 2018).

Bencana letusan Gunung Raung sejak 29 Juni 2015 juga memberikan kerugian ekonomi yang cukup besar, khususnya terkait penerbangan, pariwisata, dan bisnis (BNPB,2015). Bencana tsunami juga merupakan ancaman besar Kabupaten Banyuwangi bersama Kabupaten Pacitan dan Kabupaten Trenggalek (LPPD JATIM, 2015). Danar (2016) mengungkapkan bahwa kebijakan penanggulangan bencana tsunami di Banyuwangi dapat dilakukan melalui penguatan ketahanan komunitas antara lain perencanaan dan kebijakan yaitu dengan memperkuat kepemimpinan pengurangan resiko bencana tsunami dan perencanaan kebijakan serta anggaran. Aspek lainnya yaitu partisipasi komunitas dengan mengikutsertakan komunitas dan peran yang jelas saat terjadi situasi darurat. Aspek terakhir yaitu penguatan institusi dengan mengembangkan unit pelaksana pengurangan resiko tsunami, memberdayakan otonomi lokal dan sumberdaya manusia.

Isu kebencanaan di Kabupaten Banyuwangi telah menjadi perhatian Pemerintah Daerah (Pemda) dengan dibentuknya Organisasi Badan Penanggulangan Bencana Daerah (BPBD) sesuai Perda Nomor 16 Tahun 2011 Organisasi Dan Tata Kerja Badan Penanggulangan Bencana Daerah
Kabupaten Banyuwangi. Hal tersebut sesuai dengan Rencana Pembangunan Jangka Menengah Daerah (RPJMD) Kabupaten Banyuwangi tahun 2016-2021 pada misi ke1 yakni Mewujudkan aksesbilitas dan kualitas pelayanan bidang pendidikan, kesehatan dan kebutuhan dasar lainnya. Sehingga BPBD Kabupaten Banyuwangti berperan penting dalam menciptakan sistem penanggulangan bencana yang diharapkan akan mampu mewujudkan pelayanan prima dalam bidang Penanggulangan Bencana di Kabupaten Banyuwangi.

BPBD Kabupaten Banyuwangi mempunyai rincian tugas merencanakan, melaksanakan, mengarahkan, mengawasi dan mengendalikan kebijakan pemerintahan di bidang penanggulangan bencana dengan menyusun Rencana Strategis (Renstra). Perencanaan strategis menurut Bryson (2004) merupakan upaya disiplin untuk menghasilkan keputusan dan tindakan yang fundamental untuk membentuk dan menjadi panduan dari organisasi tentang apa, bagaimana dan mengapa dilakukan sebuah pekerjaan. Lebih tepatnya perencanaan strategis memerlukan informasi yang luas namun efektif, memperjelas misi dan isu, mengembangkan dan mengeksplorasi alternatif strategi dan menekankan pada implikasi mendatang berdasarkan keputusan saat ini.

Rencana strategis BPBD Kabupaten Banyuwangi merupakan dokumen perencanaan penanggulangan bencana untuk dijadikan acuan kerja dalam menanggulangi bencana. Perencanaan yang rasional digunakan untuk meningkatkan inovasi manajemen dalam pengambilan keputusan dan operasional pada sistem yang tidak rasional. Bryson (2004:17) mengungkapkan model perencanaan rasional merupakan bagian dari pendekatan 
deduktif dimulai dari tujuan, kebijakan, program dan tindakan untuk mencapai tujuan yang telah ditetapkan. Berbeda dengan pengambilan keputusan politik yang berangkat secara induktif dimulai dengan isu beserta konflik bukan konsensus. Konflik tersebut dapat diselesaikan apabila secara politis dapat diterima. Pada dasarnya kebijakan dan program lahir dari kesepakatan antar stakeholder yang berkepentingan atau minimal mewakili kesepakatan para pemangku kepentingan.

Oleh karena itu Renstra BPBD Kabupaten Banyuwangi harus berisi penjabaran tentang visi, misi kepala daerah yang di susun dalam dokumen RPJMD Kabupaten Banyuwangi, selanjutnya dokumen RPJMD tersebut dijadikan landasan Penyusunan Renstra Satuan Kerja Perangkat Daerah BPBD memuat sasaransasaran pokok yang harus dicapai, arah kebijakan, program-program pembangunan dan kegiatan pokok penanggulangan bencana. Bedasarkan uraian di atas BPBD Kabupaten Banyuwangi memiliki peran strategis untuk memberikan pendoman penanggulangan bencana alam dengan memperhatikan isu baik di tingkat nasional maupun tingkat lokal sehingga rumusan masalah dalam tulisan ini yaitu bagaimana perencanaan strategis BPBD Kabupaten Banyuwangi dalam penanggulangan bencana di Kabupaten Banyuwangi. Sedangkan tujuan penulisan yaitu mendeskripsikan dan menganalisis perencanaan strategis BPBD Kabupaten Banyuwangi. Manfaat yang diperoleh dari penulisan ini mampu memberikan saran penyempurnaan rencana strategis penanggulangan bencana Pemda Kabupaten Banyuwangi

\section{KAJIAN LITERATUR}

\section{Definisi Perencanaan Strategis}

World bank (2001) mendefinisikan perencanaan strategis sebuah proses yang ditentukan oleh pemimpin organisasi tentang masa depan dan bagaimana mencapainya. Agar mampu melakukannya maka dibutuhkan pengembangan terhadap masa depan visi organisasi dan menentukan prioritas, prosedur, dan strategi (operasional) untuk mencapai visi. Di dalamnya termasuk tujuan yang dapat diukur secara realistis dan dapat dicapai tetapi juga memiliki resiko tantangan. Selain itu juga menekankan pada tujuan jangka panjang daripada tujuan jangka pendek.

Melalui pencapaian orientasi jangka panjang tersebut perencanaan strategis bertujuan mempromosikan pemikiran strategis, tindakan dan pembelajaran yang bersifat on going serta didesain untuk mencapai tujuan organisasi secara komprehensif dalam memastikan tindakan misi organisasi. Selain membutuhkan perencanaan finansial juga menyertakan penilaian organisasi dan lingkungan terhadap pencapaian visi pada kondisi yang tidak bisa diprediksi di masa depan (Rezvani, et al, 2011).

Sementara menurut Bryson (2010) fungsi perencanaan strategis yaitu mendesain dan mengintegrasikan jenis-jenis pekerjaan yang harus diselesaikan secara rasional dengan memperjelas maksud organisasi, mandat, tujuan, isu, strategi dan persyaratan sukses. Fungsi selanjutnya mengatasi pekerjaan dengan membangun desain kapasitas sistem manajemen strategis, manusia, struktur, proses, sumberdaya, dukungan politik dan produktifitas. Bryson juga menyatakan perencanaan strategis dapat digunakan secara sukses oleh badan publik atau divisi organisasi utama, pemerintahan secara umum (daerah, kota, negara), organisasi nonprofit yang menyediakan layanan publik, jaringan interorganisasi (kolaborasi, 
kemitraan) dan organisasi nonprofit dengan fungsi spesifik (transportasi, kesehatan, pendidikan, layanan darurat) dan seluruh komunitas seperti wilayah kota, regional atau negara (Rezvani, et al, 2011).

Manfaat perencanaan strategis bagi organisasi menurut Bryson (2004:11-12) pertama promosi pemikiran yang strategis, bertindak, dan belajar, terutama melalui dialog dan percakapan strategis antara aktor kunci. Pemikiran strategis, bertindak, dan pembelajaran yang dipromosikan oleh pengumpulan yang sistematis tentang lingkungan eksternal dan internal informasi organisasi dan kepentingan berbagai pelaku, bijaksana pemeriksaan keberhasilan organisasi dan kegagalan, klarifikasi dari arah masa depan, pembentukan prioritas organisasi untuk tindakan, dan secara umum, memperhatikan akuisisi dan penggunaan pengetahuan dan keterampilan.

Manfaat kedua adalah pengambilan keputusan yang lebih baik. Peningkatan keputusan sangat penting, karena penelitian terbaru mengindikasikan bahwa setidaknya setengah dari semua keputusan strategis gagal sebagai hasil dari proses pengambilan keputusan miskin. Ketiga adalah peningkatan efektivitas organisasi. Organisasi-organisasi yang terlibat dalam perencanaan strategis didorong untuk memperjelas dan isu-isu utama organisasi, menanggapi dengan bijak internal dan tuntutan eksternal dan tekanan (termasuk akuntabilitas), dan menangani secara efektif dengan keadaan yang berubah dengan cepat.

Keempat, melampaui efektivitas organisasi, perencanaan strategis dapat meningkatkan efektivitas sistem sosial yang lebih luas. Sebagian besar masalah umum yang kita hadapi hari ini peregangan di luar batas-batas setiap satu organisasi. Donald Schön (1971) menunjukkan tantangan besar dalam pendidikan, Kesehatan, lapangan kerja, kemiskinan, lingkungan - biasanya perlu akan dikonseptualisasikan di supraorganizational, atau sistem, tingkat dan bukan tingkat organisasi. Sistem-sistem adalah apa yang perlu bekerja lebih baik jika hidup kita dan dunia harus dibuat lebih baik. Organisasi dapat berkontribusi untuk berfungsi lebih baik dari sistem ini tetapi biasanya harus melakukannya dalam kemitraan dengan pihak lain. Kelima, menguntungkan pihak yang terlibat. Pembuat kebijakan dan pembuatan keputusan kunci dapat membantu memenuhi peran dan tanggungjawab mereka dan peserta di dalam proses dapat meningkatkan keahlian dan kerjasama tim.

\section{Perencanaan Strategis ABC}

Perencanaan strategis ABC merupakan sebuah ringkasan tentang apa saja yang termuat di dalam perencanaan strategis. Penjelasan dapat diuraikan sebagai berikut, A adalah mencari tahu di mana Anda berada, B adalah mencari arah kemana anda ingin pergi, dan $C$ adalah mencari tahu bagaimana untuk sampai ke sana. Manajer dan para pemimpin datang untuk memahami A, B, dan C sebagaimana mereka merumuskan, mengklarifikasi, dan menyelesaikan masalah-masalah strategisdasar pilihan-pilihan kebijakan atau tantangan organisasi untuk wajah. Konten dari A dan B adalah organisasi yang ada atau misi baru, struktur dan sistem, komunikasi, program dan layanan, orang dan keterampilan, hubungan, anggaran, dan mendukung lainnya. Isi $C$ adalah rencana strategis; rencana untuk berbagai fungsi; cara untuk merancang ulang, menyusun ulang, atau reengineer; alokasi anggaran; dan kendaraan lainnya untuk perubahan. Mendapatkan dari A ke C melibatkan menjelaskan visi, misi, dan tujuan. 


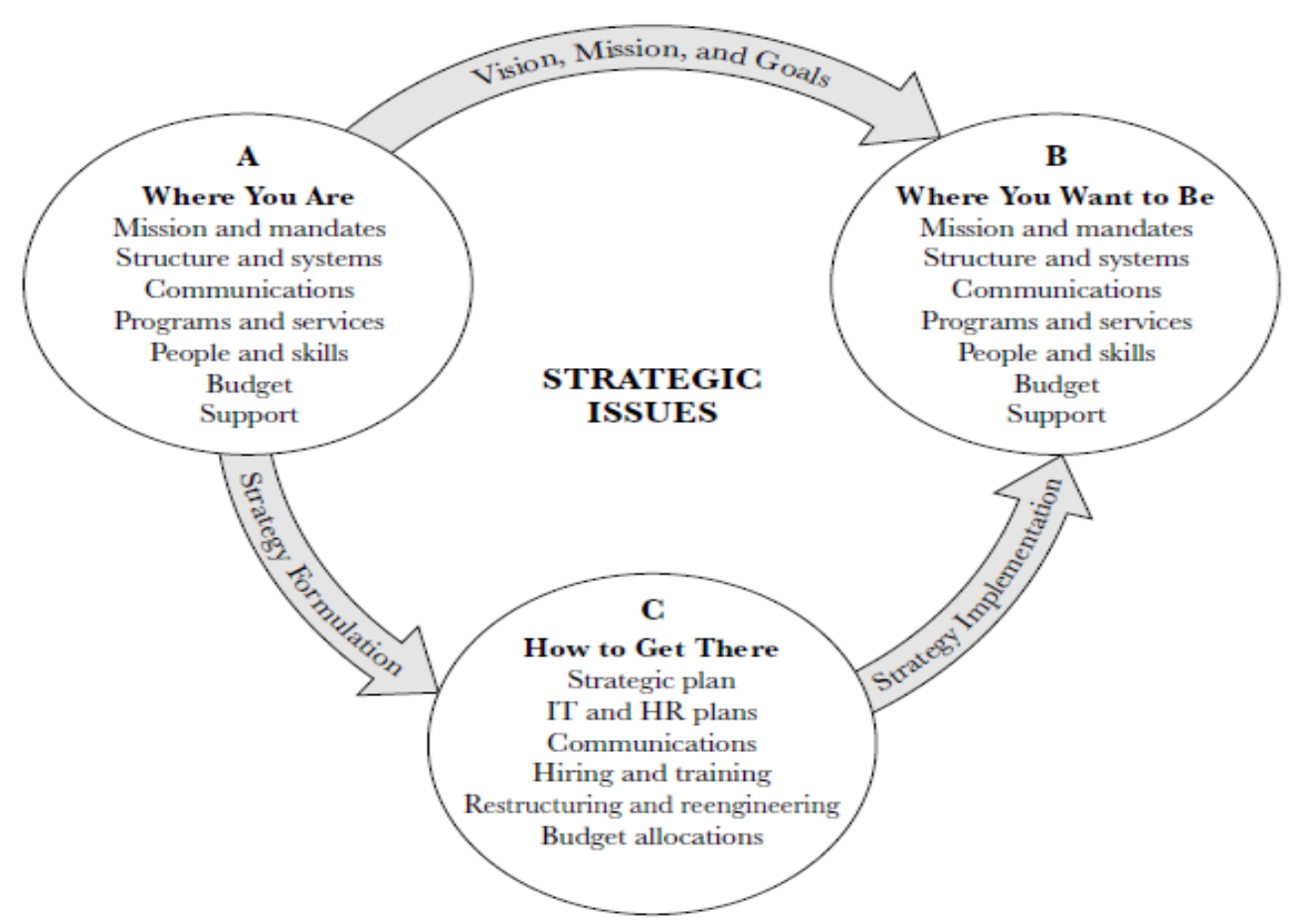

Gambar 1.

Perencanaan strategis ABC

Sumber: Bryson (2004)

Mendapatkan dari A ke C adalah proses perumusan strategi, sedangkan mendapatkan dari C ke B adalah strategi implementasi. Untuk melakukan perencanaan strategis yang baik, perlu mencari A, B, dan C, dan bagaimana mereka harus terhubung. Dengan memahami isuisu bahwa A, B, C, dan mereka dapat interkoneksi secara efektif. Ringkasan ini juga menjadikannya jelas bahwa perencanaan strategis tidak satu hal tapi serangkaian konsep, prosedur, dan peralatan.

\section{Pedekatan identifikasi isu strategis}

Berikut dijelaskan secara ringkas tujuh pendekatan untuk mengindentifikasi isu strategis. Pendekatan tersebut tergantung sifat lingkungan dan organisasi atau karakteristik komunitas (Bryson, 2004:161-164),
1. Pendekatan Langsung;

Pendekatan ini kemungkinan banyak digunakan oleh pemerintah dan organisasi non profit. Perencana langsung mereview mandat, misi dan SWOC untuk mengidentifikasi isu-isu strategis. Pendekatan langsung sangat baik ketika tidak ada persetujuan pada tujuan atau tujuan yang disetujui masih terlalu abstrak; tidak ada prakondisi vision of success dan mengembangkan visi secara konsensus sulit dilakukan; tidak ada kewenangan hierarkis yang dapat memaksakan tujuan pada stakeholder lain; lingkungan yang bergolak sehingga tujuan pada visi terlihat tidak bijak, parsial untuk segera ditindaklanjuti, terlihat isu-isu yang paling tepat. Dengan kata lain Pendekatan langsung dapat bekerja secara pluralistik, partisan, dipolitisasi dan relatif terfragmentasi pada 
sebagian besar organisasi publik sebagai koalisi dominan yang cukup kuat dan cukup tertarik untuk membuat pendekatan tersebut mampu bekerja. Intinya harus ada komitmen koalisi untuk mengidentifikasi dan resolusi beberapa isu strategis kunci yang dihadapi oleh organisasi bahkan jika anggota koalisi tidak berkomitmen untuk mengembangkan tujuan atau vision of succes secara komprehensif.

2. Pendekatan tujuan.

Pendekatan ini lebih kepada teori perencanaan tradisional bahwasannya organisasi pertama kali menekankan pada tujuan dan sasaran kemudian menuju pada identifikasi isu-isu yang dibutuhkan untuk mencapai tujuan dan sasaran tersebut atau langsung mengembangkan strategi. Semakin meningkatnya tujuan dan sasaran dalam balanced score card pada perencanaan strategis isu-isunya berkonsentrasi pada cara terbaik pencapaian apa yang ada di dalam scorecard. Pendekatan ini dapat bekerja dengan baik di organisasi yang memiliki struktur hierarkis yang mana pembuat keputusan kunci dapat memaksakan tujuan pada sesuatu hal lain oleh perencanaan dan tidak ada peneyebaran antara tujuan resmi dan tujuan operasional.

3. Vision of succes.

Pendekatan ini menekankan pada anggota organisasi tentang bagaimana mengembangkan gambar terbaik organisasi di masa depan sebagai bagian dari pemenuhan misi misi dan pencapaian/ mengusahakan sukses tersebut. Isu-isu yang dipertanyakan yaitu bagaimana organisasi seharusnya bergerak pada posisi saat ini menuju arah yang bisa dan mampu direalisasikan kesuksesan visi tersebut. Pendekatan ini dikembangkan melalui 8 tahap proses perencanaan strategis. Kesemuanya itu dibutuhkan tahap kondisi saat ini yang relatif pendek, penggambaran yang diidealkan dari masa depan organisasi. Vision of success sangat bermanfaat ketika pendekatan holistik organisasi penting dilakukan dan beserta strateginya menyangkut intergrasi lintas batas organisasi, level atau fungsi organisasi. Pendekatan ini biasanya digunakan oleh organisasi non profit dari pada organisasi publik karena organisasi publik lebih dibatasi oleh mandat serta bertentangan dengan banyak stakeholder. Namun bagaimanapun juga pendekatan ini sangat berguna bagi organisasi publik jika pemimpin yang terpilih setuju dan merupakan bagian dari visi untuk masa depan yang penuh resiko. Selain itu pendekatan ini juga bisa digunakan untuk komunitas yang homogen, konsensus nilai atau mengembangkan konsensus. Pendekatan inilah yang digunakan untuk mendeskripsikan rencana strategis terkait konsistensi visi pembangunan jangka menengah baik tingkat pusat hingga daerah yang diterjemahkan oleh kepala daerah terpilih untuk selanjutnya dirumuskan strategi organisasi oleh BPBD Kabupaten Banyuwangi.

4. Pendekatan tidak langsung.

Pendekatan ini bekerja pada situasi yang sama sebagai pendekatan langsung khususnya ketika pengalihan strategi utama diperlukan tetapi banyak anggota tim perencanaan dan organisasi belum memahami kebutuhan tersebut. Metode ini dimulai dengan partisipan sistem yang ada dari ide-ide dan membantu mereka mengelaborasi dampak tindakan dari ideide. Kemudian mengkombinasikan kembali ide yang baru bersifat konstruksi sosial. Sebagai konsekuensinya inovasi lebih dibutuhkan dari sekedar mutasi. Ketika menggunakan pendekatan ini tim perencana menseting beberapa pilihan, menggabungkan, dan mensortir kombinasi 
di dalam kluster-kluster yang memiliki kemiripan. Seting atau aturan tersebut terdiri dari 1) membuat atau menjaga kesenangan stakeholder pada kriteria kepuasan mereka 2) membangun kekuatan, mengambil keuntungan dari peluang dan meminimalisir kelemahan dan tantangan secara berlebihan 3) memenuhi misi dan mandat dan membuat nilai publik secara umum 4) menangkap tujuan saat ini, strategi kepercayaan dan detailnya 5) mengartikulasikan tindakan atau menyarankan di dalam latar belakang studi yang relevan .

5. Pendekatan pemetaan oval (oval mapping).

Pendekatan ini menyertakan kata dan diagram panah dimana tindakan yang potensial akan diambil oleh organisasi, bagaimana tindakan akan diambil, dan mengapa dihubungkan oleh panah yang mengindikasikan sebab dan efek atau pengaruh hubungan antar panah tersebut. Mapping ini terdiri beberapa ratus relasi yang saling terkait, menunjukkan wilayah dari kepentingan dan hubungan satu dengan yang lainnya

6. Pendekatan tensi isu.

Terdapat empat dasar tensi diantara isu strategis yaitu sumberdaya manusia (terutama keadilan), inovasi dan perubahan, perawatan tradisi dan peningkatan produktivitas. Penggunaan pendekatan ini digunakan ketika biaya dalam kesalahan memframing isu sangat tinggi atau ketika terdapat ketidakpastian tentang isu sebenarnya.

7. Analisis sistem.

Pendekatan ini dapat digunakan untuk melihat cara terbaik untuk memframing isu yang dapat dikonseptualisasikan sebagai sebuah sistem dan ketika sistem berisikan umpan balik yang kompleks sehingga diharuskan membuat model dalam memahami sistem. Analisis ini membutuhkan dukungan analisis secara komputis. Jika sistem lebih kompleks akan lebih sulit untuk membuat model dan membutuhkan tenaga ahli. Kelemahan dari sistem analisis itu sendiri karena sistem tidak bisa dipahami oleh metodologi yang ada saat ini.

\section{METODE PENELITIAN}

Metode penelitian menggunakan pendekatan kualitatif. Tujuan penelitian kualitatif yaitu untuk mengungkap permasalahan dalam kehidupan kerja baik di organisasi pemerintah, swasta, kemasyarakatan, kepemudaan, perempuan, olah raga, seni dan budaya, dan sebagainya guna memperoleh kebijakan yang akan ditetapakan (Nilamsari, 2014). Sedangkan jenis peneltian yaitu studi dokumen resmi rencana strategis BPBD Kabupaten Banyuwangi tahun 2016-2021. Dokumen tersebut sebagai sumber utama dalam mengkaji rencana strategis penanggulangan bencana di Kabupaten Banyuwangi menggunakan pendekatan vision of success dari John M. Bryson.

Pendekatan inilah yang digunakan untuk mendeskripsikan rencana strategis terkait konsistensi visi pembangunan jangka menengah baik tingkat pusat hingga daerah yang diterjemahkan oleh kepala daerah terpilih untuk selanjutnya dirumuskan strategi organisasi oleh BPBD Kabupaten Banyuwangi. Pendekatan tersebut mampu memberikan hasil deskriptif secara holistik terhadap organisasi beserta strateginya menyangkut intergrasi lintas batas organisasi, level atau fungsi organisasi. Selain itu, komitmen pemimpin terpilih juga menjadi pertimbangan penting untuk masa depan sesuai visi organisasi yang penuh resiko. Analisis yang digunakan dalam penelitian ini yaitu analisis isi (content analysis) dengan memeriksa dokumen secara sistematik bentuk-bentuk komunikasi yang dituangkan secara tertulis dalam bentuk dokumen dengan obyektif. 
Definisi lain menurut Moleong (2007 220) bahwa analisis isi adalah teknik apapun yang digunakan untuk menarik kesimpulan melalui usaha menemukan karakteristik pesan, dan dilakukan secara objektif, dan sistematis.

\section{HASIL DAN PEMBAHASAN Visi Renstra BPBD Kabupaten Banyuwangi}

Penanggulangan bencana secara nasional telah diatur dalam UndangUndang Nomor 24 Tahun 2007 dengan Badan Nasional Penanggulangan Bencana di tingkat pusat dan badan penanggulangan bencana daerah di tingkat daerah dimana hubungan kerja bersifat koordinasi dan teknis kebencanaan sebagai upaya penyelenggaraan penanggulangan bencana yang berkualitas. Disamping itu Undangundang nomor 25 tahun 2004 tentang sistem perencanaan pembangunan nasional, undang-undang nomor 23 tahun 2014 tentang pemerintahan daerah dan undangundang nomor 33 tahun 2004 tentang perimbangan keuangan antara pusat dan daerah menjadi dasar RPJMD didasarkan pada visi dan misi kepala daerah. Kemudian RPJMD ini menjadi landasan penyusunan Renstra Satuan kerja perangkat daerah selama 5 tahun ke depan. Dengan begitu Renstra BPBD Kabupaten Banyuwangi berpedoman pada RPJMD 2016-2021 Kabupaten Banyuwangi (Tabel 1).

Table 1.

Keterkaitan RPJMN, RPJMD dan RTRW

\begin{tabular}{|l|l|l|}
\hline RPJMN & $\begin{array}{l}\text { RPJMD Kabupaten } \\
\text { Banyuwangi }\end{array}$ & RTRW Kabupaten Banyuwangi \\
\hline $\begin{array}{l}\text { Visi: } \\
\text { Yerwujudnya Indonesia } \\
\text { Dan Berdaulat, Mandiri, }\end{array}$ & $\begin{array}{l}\text { Misi ke-1: } \\
\text { Mewujudkan Aksesibilitas } \\
\text { dan }\end{array}$ & $\begin{array}{l}\text { Misi ke-1: } \\
\text { Mewujudkan pengelolaan kawasan } \\
\text { lindung, kawasan budidaya, dan } \\
\text { pengendalian kawasan rawan } \\
\text { bencana secara harmonis dan } \\
\text { berkelanjutan; }\end{array}$ \\
$\begin{array}{l}\text { Berkepribadian } \\
\text { Rerlandaskan Gotong- }\end{array}$ & Kualitas Pelayanan Bidang \\
$\begin{array}{l}\text { Misi ke-6: } \\
\begin{array}{l}\text { Mewujudkan Indonesia } \\
\text { menjadi negara maritim } \\
\text { yang mandiri, } \\
\text { maju, kuat, dan } \\
\text { berbasiskan kepentingan } \\
\text { nasional. }\end{array}\end{array}$ & $\begin{array}{l}\text { Pendidikan, Kesehatan dan } \\
\text { Kebutuhan Dasar Lainnya }\end{array}$ & $\begin{array}{l}\text { Kebijakan: } \\
\text { Pengendalian kawasan rawan } \\
\text { bencana alam; }\end{array}$ \\
Sasaran: & $\begin{array}{l}\text { Keningkatnya } \\
\text { Ketenteraman, } \\
\text { Ketertiban Umum dan } \\
\text { Perlindungan Masyarakat }\end{array}$ & \\
& & \\
&
\end{tabular}




\begin{tabular}{|l|l|l|}
\hline RPJMN & $\begin{array}{l}\text { RPJMD Kabupaten } \\
\text { Banyuwangi }\end{array}$ & RTRW Kabupaten Banyuwangi \\
\hline Melestarikan Sumber & & \\
Daya Alam, Lingkungan \\
Hidup dan Pengelolaan \\
Bencana & & \\
Sasaran: & & \\
1. Menurunnya indeks & & \\
risiko bencana pada & & \\
pusat-pusat & \\
pertumbuhan yang & & \\
berisiko tinggi. & \\
2. Meningkatnya & & \\
penanganan perubahan & & \\
iklim, sistem peringatan & & \\
dini, tersedianya data & & \\
dan informasi perubahan & & \\
iklim dan ketepatan serta & & \\
akurasi data BMKG & & \\
\hline
\end{tabular}

Sumber: hasil olahan

Visi misi dalam rencana

Renstra BPBD Kabupaten Banyuwangi Pembangunan Jangka Menengah Nasional 2015-2019 sesuai presiden terpilih yaitu “Terwujudnya Indonesia Yang Berdaulat, Mandiri, Dan Berkepribadian Berlandaskan Gotong-Royong" telah mengakomodir strategi penanggulangan bencana alam melalui pengurangan resiko bencana serta penguatan data dan informasi bencana alam. Sasaran tersebut merupakan pengejawantahan dari Nawa Cita Presiden terpilih dengan agenda prioritas pelestarian Sumberdaya alam, lingkungan hidup dan pengelolaan bencana. RPJMN tersebut dijadikan pedoman bagi pemerintah mengacu pada Rencana Tata Ruang

Wilayah untuk pengelolaan bencana alam. pengelolaan bencana alam.

Dijadikannya RPJMD menjadi pedoman renstra dapat dilihat pada visi menggunakan visi dari bupati terpilih yaitu “Terwujudnya Masyarakat Banyuwangi yang semakin sejahtera, mandiri dan berakhlak mulia melalui peningkatan perekonomian dan kualitas sumberdaya manusia". Sementara itu untuk mewujudkan visi tersebut diperlukan upaya untuk mencapainya yaitu melalui misi. Adapun misi yang dicanangkan oleh BPBD Kabupaten Banyuwangi

(bpbd.banyuwangikab.go.id) adalah 1) Melindungi masyarakat dari ancaman bencana melalui pengurangan risiko bencana 2) Membangun sistem penanggulangan bencana yang handal 3) Menyelenggarakan penanggulangan bencana secara terencana, terpadu dan menyeluruh. Berikut tabel sinkronisasi rencana strategis dari BPBD Kabupaten Banyuwangi: 
Tabel 2

Sinkronisasi Renstra

\begin{tabular}{|c|c|c|c|}
\hline Renstra BNPB & Renstra BPBD & \multicolumn{2}{|c|}{ Renstra BPBD Kabupaten Banyuwangi } \\
\hline $\begin{array}{l}\text { Tujuan: } \\
\text { 1. Terwujudnya } \\
\text { kesadaran, } \\
\text { kesiapan dan } \\
\text { kemampuan } \\
\text { (pemerintah dan } \\
\text { masyarakat) } \\
\text { dalam upaya } \\
\text { penanggulangan } \\
\text { bencana; }\end{array}$ & $\begin{array}{l}\text { Sasaran: } \\
\text { 1. Pengurangan } \\
\text { Resiko Bencana } \\
\text { yaitu a) } \\
\text { tumbuhnya } \\
\text { budaya siaga } \\
\text { becana baik } \\
\text { masyarakat dan } \\
\text { aparat b) } \\
\text { terbitnya } \\
\text { peraturan }\end{array}$ & $\begin{array}{l}\text { Tujuan: } \\
\text { 1. Rasio pengurangan } \\
\quad \text { resiko bencana } \\
\quad \text { pada KRB } \\
\text { Sasaran: } \\
\text { Meningkatnya } \\
\text { Manajemen } \\
\text { Penanggulangan } \\
\text { bencana di } \\
\text { Masyarakat }\end{array}$ & \\
\hline Sasaran: & penanggulangan & Indikator sasaran: & Strategi \\
\hline $\begin{array}{l}\text { meningkatnya } \\
\text { kapasitas } \\
\text { ketangguhan daerah } \\
\text { dalam } \\
\text { menghadapi } \\
\text { bencana melalui } \\
\text { upaya pencegahan } \\
\text { dan kesiapsiagaan } \\
\text { bencana; } \\
\text { meningkatnya } \\
\text { kualitas } \\
\text { administratif dan } \\
\text { sumberdaya } \\
\text { manusia. }\end{array}$ & $\begin{array}{l}\text { bencana yang } \\
\text { memadai c) } \\
\text { meningkatnya } \\
\text { dukungan } \\
\text { fasilitas dan } \\
\text { utilitas pelayanan } \\
\text { umum d) } \\
\text { menurunnya } \\
\text { derajat } \\
\text { kerentanan KWB }\end{array}$ & $\begin{array}{l}\text { IS.1 Persentase resiko } \\
\text { bencana pada KRB } \\
\text { IS.2 Persentase desa } \\
\text { tangguh bencana di } \\
\text { KRB }\end{array}$ & $\begin{array}{l}\text { IS.1 Mengoptimalkan } \\
\text { pembentukan fasilitator } \\
\text { Bencana yang dibentuk } \\
\text { IS.2 Mengoptimalkan } \\
\text { pembentukan } \\
\text { desa/kelurahan tangguh } \\
\text { (Destana) }\end{array}$ \\
\hline Tujuan: & Sasaran: & Tujuan: & \\
\hline $\begin{array}{l}\text { 2. Terwujudnya } \\
\text { sistem } \\
\text { penanganan } \\
\text { kedaruratan } \\
\text { bencana yang } \\
\text { efektif melalui } \\
\text { peningkatan } \\
\text { koordinasi } \\
\text { penanganan } \\
\text { kedaruratan, } \\
\text { peningkatan } \\
\text { sarana dan } \\
\text { prasarana, serta }\end{array}$ & $\begin{array}{l}\text { 2. Penanganan } \\
\text { bencana yang } \\
\text { responsif yaitu a) } \\
\text { terhimpunnya } \\
\text { sumberdaya } \\
\text { secara terpadu } \\
\text { dalam } \\
\text { penanganan } \\
\text { bencana b) } \\
\text { terselenggarannya } \\
\text { pertolongan cepat } \\
\text { dan tepat sasaran } \\
\text { saat kejadian }\end{array}$ & $\begin{array}{l}\text { 2. } \begin{array}{l}\text { Persentase } \\
\text { penanganan } \\
\text { bencana yang } \\
\text { sesuai SOP }\end{array} \\
\text { Sasaran: } \\
\text { Terwujudnya } \\
\text { penanggulangan } \\
\text { bencana yang sesuai } \\
\text { dengan } \\
\text { standar operasional } \\
\text { prosedur (SOP) }\end{array}$ & \\
\hline peningkatan & bencana & & Strategi \\
\hline
\end{tabular}




\begin{tabular}{|c|c|c|c|}
\hline Renstra BNPB & Renstra BPBD & \multicolumn{2}{|c|}{ Renstra BPBD Kabupaten Banyuwangi } \\
\hline $\begin{array}{l}\quad \begin{array}{l}\text { sistem logistik } \\
\text { dan peralatan }\end{array} \\
\quad \text { penanggulangan } \\
\text { bencana. }\end{array}$ & & $\begin{array}{l}\text { Indikator sasaran: } \\
\text { IS.1 Persentase } \\
\text { Korban } \\
\text { bencana tertangani } \\
\text { IS.2 Persentase } \\
\text { Pemenuhan } \\
\text { kebutuhan dasar } \\
\text { IS.3 Persentase } \\
\text { Pemulihan kerusakan } \\
\text { bencana yang } \\
\text { tertangani }\end{array}$ & $\begin{array}{l}\text { IS.1 Mengoptimalkan } \\
\text { akurasi updating data } \\
\text { kebencanaan di } \\
\text { PUSDALOPS } \\
\text { IS.2 Mencukupi } \\
\text { kebutuhan dasar saat } \\
\text { terjadi tanggap darurat } \\
\text { bencana } \\
\text { IS.3 Meningkatkan } \\
\text { pemenuhan sarana dan } \\
\text { prasarana pasca bencana }\end{array}$ \\
\hline $\begin{array}{l}\text { Tujuan: } \\
\text { 3. Terwujudnya } \\
\text { upaya } \\
\text { rehabilitasi dan } \\
\text { rekonstruksi } \\
\text { yang lebih baik. } \\
\text { Sasaran: } \\
\text { Terwujudnya } \\
\text { Akuntabilitas dan } \\
\text { good governance }\end{array}$ & \begin{tabular}{|l} 
Sasaran: \\
3. \\
pemulihan \\
kawasan \\
terdampak pasca \\
bencana yaitu a) \\
tersusunnya \\
rencana \\
pemulihan \\
bencana secara \\
partisipatif b) \\
tersedianya \\
standar \\
kesejahteraan \\
minimun korban \\
bencana c) \\
pulihnya daya \\
dukung fasilitas \\
dan utilitas \\
pelayanan umum
\end{tabular} & & \\
\hline
\end{tabular}

Sumber: hasil olahan

Penentuan strategi penanganan bencana secara nasional terdapat pada BNPB dengan menitik beratkan pada aspek kesiapan dalam menghadapi bencana beserta upaya administratif di tingkat daerah. Pada tahap tanggap darurat mengupayakan pemenuhan kapasitas sumberdaya, logistik, pelayanan korban bencana dan sosialisasi penanganan tanggap darurat. Sedangkan pada tahap pasca bencana pelibatan aktor dalam good governance menjadi sasaran untuk mewujudkan pemulihan pasca bencana. sasaran penanggulangan bencana BPBD 
Provinsi Jawa Timur menekankan pada pengurangan resiko bencana melalui indentifikasi Kawasan Rawan Bencana (KWB), kesadaran lokal terhadap bencana serta pemenuhan pelayanan untuk penanggulangan bencana. Sedangkan untuk tahap tanggap darurat dan pasca bencana memiliki sasaran pertolongan yang responsif serta tepat sasaran dan tersedianya rencana pemulihan, kebutuhan minimal bagi korban yang terdampak bencana.

Sinkronisasi dokumen renstra tabel 2 merupakan upaya secara konsisten dari BPBD Kabupaten Banyuwangi dalam menyusun strategi. Renstra BPBD Kabupaten Banyuwangi mengacu rencana strategis BNPB dan BPBD Provinsi Jawa Timur berdasarkan tujuan hingga sasaran yang diterjemahkan melalui strategi. mencakup pengurangan resiko bencana. Artinya strategi pra bencana dilalukan melalui strategi meminimalisir resiko bencana aspek Sumbedaya Manusia dan pelibatan komunitas desa. Tahap tanggap darurat dilakukan melalui strategi optimalisasi PUSDALOPS (Pusat Kendali Operasi) dan pemenuhan kebutuhan dasar darurat bencana serta peningkatan pemulihan sarana dan prasarana pasca bencana.

\section{Arah Strategi Organisasi}

Untuk menentukan strategi perlu dilakukan analisis terlebih dahulu terhadap situasi dan kondisi baik lingkungan internal maupun lingkungan eksternal. Hal tersebut dimaksudkan untuk menentukan kebijakan yang akan diambil. Bryson (2004:125-126) mengatakan bahwa melalui analisis kekuatan, kelemahan, Peluang dan tantangan (SWOC) membantu tim organisasi untuk mengidentifikasi faktor kunci sukses atau faktor kritis sukses. SWOC merupakan pembaruan dari SWOT dimana threats lebih mempersepsikan sesuatu yang rigid atau sesuatu yang memiliki ancaman beresiko tinggi sehingga kata challenges lebih bermakna netral untuk mendorong pertimbangan kemungkinan jangkauan tindakan di masa depan Dengan demikian SWOC memuat tindakan yang akan dilakukan, kriteria yang harus dipenuhi atau indikator kinerja untuk bertahan. Lebih dari itu kompetensikapabilitas dari serangkaian tindakan strategi; kompetensi khusus-kompetensi yang sulit ditiru pihak lain; dan kemampuan utama-faktor kunci kesuksesan dan memproduksi nllai publik juga dapat secara jelas diketahui pada organisasi tersebut.

SWOC Renstra BPBD Kabupaten Banyuwangi memuat kompetensi utama dan kompetensi khusus sebagai organisasi dari pemerintah daerah yang khusus menangani persoalan kebencanaan di daerah. Adapun strategi tersebut dirumuskan beberapa potensi, permasalahan serta alternatif sebagai berikut:

Strength:

1. Mendayagunakan undang-undang dan peraturan tentang penanggulangan bencana dalam menunjang pemenuhan kebutuhan dasar.

2. Sebagai lembaga yang khusus dibentuk menangani bencana/unsur komando.

\section{Weakness:}

1. Sulitnya melakukan koordinasi saat kejadian bencana yang memerlukan penanganan segera.

2. Minimnya peralatan kebencanaan yang dimiliki.

Opportunity:

1. Besarnya minat relawan untuk terlibat kegiatan penanggulangan bencana. 
2. Kemandirian masyarakat dalam $\begin{aligned} & \text { bagi masyarakat kawasan rawan } \\ & \text { menghadapi melalui }\end{aligned}$ bencana;
bencana pembentukan desa tangguh

3. Sistem peringatan dini kebencanaan di BMKG.

Challenges:

1. Perubahan dan perkembangan peraturan bidang Penanggulangan Bencana Daerah

3. Era globalisasi dan kemajuan Iptek yang menuntut perkembangan sistem.

4. perubahan cuaca ekstrim dan bencana sosial. Asumsi masyarakat yang mengabaikan ancaman bencana.

2. Adanya tuntutan pelayanan penanggulangan bencana yang lebih baik

Tabel 3.

Analisis SWOC

\begin{tabular}{|c|c|c|c|}
\hline \multirow{2}{*}{\multicolumn{2}{|c|}{$\begin{array}{l}\text { Strength,Weakness, } \\
\text { Opportunity, } \\
\text { Challenges }\end{array}$}} & \multicolumn{2}{|c|}{ Internal } \\
\hline & & STRENGTH & WEAKNESS \\
\hline \multirow{8}{*}{ 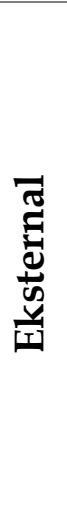 } & \multirow[t]{6}{*}{ OPPORTUNITY } & \multirow{6}{*}{$\begin{array}{l}\text { Optimalisasi Manajemen } \\
\text { organisasi serta } \\
\text { penguatan tugas dan } \\
\text { fungsi penanggulangan } \\
\text { bencana secara } \\
\text { komprehensif. }\end{array}$} & Meningkatkan \\
\hline & & & Koordinasi dengan \\
\hline & & & pihak eksternal untuk \\
\hline & & & kebutuhan teknis \\
\hline & & & maupun prosedural \\
\hline & & & $\begin{array}{l}\text { dalam penanggulangan } \\
\text { bencana. }\end{array}$ \\
\hline & \multirow[t]{2}{*}{ CHALLENGES } & Mengingkatkan kualitas & Peningkatan upaya \\
\hline & & $\begin{array}{l}\text { sumberdaya manusia } \\
\text { organisasi. }\end{array}$ & mitigasi bencana. \\
\hline
\end{tabular}

Sumber: BPBD Kabupaten Banyuwangi

Hasil dari SWOC tabel 3 dapat diketahui strategi Badan Penanggulangan Bencana Daerah Kabupaten Banyuwangi yaitu pertama, Optimalisasi Manajemen organisasi serta penguatan tugas dan fungsi penanggulangan bencana secara komprehensif. Hal ini ditujukan untuk percepatan reformasi birokrasi dengan penekanan mitigasi bencana serta untuk menunjang keberhasilan tujuan dan sasaran Perangkat Daerah, perlu adanya dukungan sistem dan manajemen penanggulangan bencana yang efektif dan efisien, sehingga percepatan optimalisasi pada konteks ini perlu dan mendesak untuk di aplikasikan. Kedua, meningkatkan koordinasi dengan pihak eksternal dalam penanggulangan bencana. strategi ini diperlukan agar organisasi mampu berkerja secara optimal pada setiap tahapan manajemen bencana terutama pada tahap tanggap darurat dengan menggandeng pihak swasta dan masyarakat serta berbagai pihak yang berkompeten terhadap persoalan bencana alam. Selain itu kelemahan lainnya berupa kurangnya peralatan kebencanaan yang semula berada pada tantangan organisasi, dimasukkan pada aspek kelemahan internal organisasi karena menyangkut peratalan internal organisasi. Sehingga upaya koordinasi yang baik juga melibatkan pihak luar untuk penyediaan peralatan siap pakai tanggap darurat. 
Strategi ke tiga, mengingkatkan kualitas sumberdaya manusia organisasi dan Peningkatan upaya mitigasi bencana. Strategi ini dlilakukan untuk memanfaatkan kekuatan untuk menghadapi tantangan perubahan baik normatif, subtantif dan perubahan alam. Dalam rangka peningkatan kapasitas masyarakat menghadapi perubahan penanggulangan bencana maka perlu dilakukan pengingkatan kualitas sumberdaya manusia agar lebih mampu beradaptasi dan menyesuaikan dengan perubahan lingkungan organisasi. Strategi ke empat, peningkatan upaya mitigasi bencana. strategi keempat ini merupakan strategi menghindari kelemahan dan mengelak dari ancaman. Tahap mitigasi bencana dilakukan pada tahap pra bencana sehingga dengan mengoptimalkan sumberdaya organisasi mulai dari tahapan awal diharapkan kegiatan penanggulangan bencana dapat berdampak positif pada kegiatan tanggap darurat bencana dan pasca bencana.
Proses perencanaan strategis ini berkaitan dengan pemikiran strategis, tindakan dan pembelajaran untuk mengekplorasi secara detail melalui sepuluh tahap strategi siklus perubahan. Tahapan ini didesain untuk mengorganisasi partisipasi, membuat ide intervensi terhadap strategi, koalisi pemenangan dan implementasi strategi. Sepuluh tahap tersebut menurut Bryson (2004:32) meliputi (1) Inisiasi dan persetujuan pada proses perencanaan strategi (2) Identifikasi Mandat Organisasi (3) Memperjelas Misi Organisasi dan Nilai (4) Menilai Lingkungan Eksternal dan Internal (5) Identifikasi Isu Strategis yang dihadapi Organisasi (6) Merumuskan Strategi untuk Mengelola Isu (7) Ulasan dan Mengadopsi Strategi atau Rencana Strategis (8) Membentuk Visi Organisasi yang Efektif (9) Mengembangkan Proses Implementasi Efektif (10) menilai kembali Strategi dan Proses Perencanaan Strategis.

Tabel 4.

10 Tahapan Perencanaan Strategis

\begin{tabular}{|c|c|c|}
\hline Tahapan bryson & Indikator & Evaluasi Renstra BPBD \\
\hline $\begin{array}{l}\text { 1. Inisiasi dan } \\
\text { persetujuan pada } \\
\text { proses perencanaan } \\
\text { strategi }\end{array}$ & $\begin{array}{l}\text { - } \begin{array}{l}\text { Tujuan dan manfaat } \\
\text { manajemen strategis }\end{array} \\
\text { - Keterlibatan } \\
\text { organisasi, unit grup } \\
\text { dan individu } \\
\text { - Langkah spesifik } \\
\text { yang akan } \\
\text { dilaksanakan } \\
\text { - Format dan waktu } \\
\text { dari laporan }\end{array}$ & 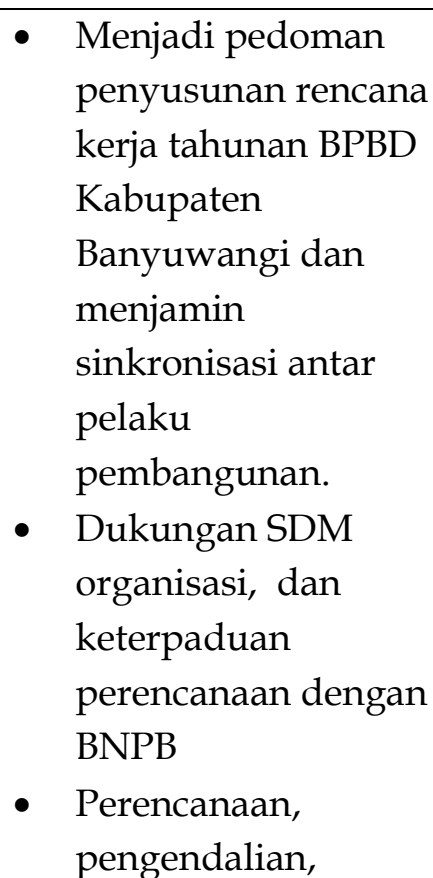 \\
\hline
\end{tabular}




\begin{tabular}{|c|c|c|}
\hline Tahapan bryson & Indikator & Evaluasi Renstra BPBD \\
\hline & & $\begin{array}{l}\text { koordinasi dan } \\
\text { pembinaan } \\
\text { penanggulangan } \\
\text { bencana di daerah. } \\
\text { - } \text { Berpedoman pada } \\
\text { RPJMD Kabupaten } \\
\text { Banyuwangi 2016- } \\
2021 \text { berbentuk } \\
\text { dokumen. }\end{array}$ \\
\hline $\begin{array}{ll}\text { 2. } & \text { Identifikasi } \\
\text { Organisasi } & \text { Mandat }\end{array}$ & 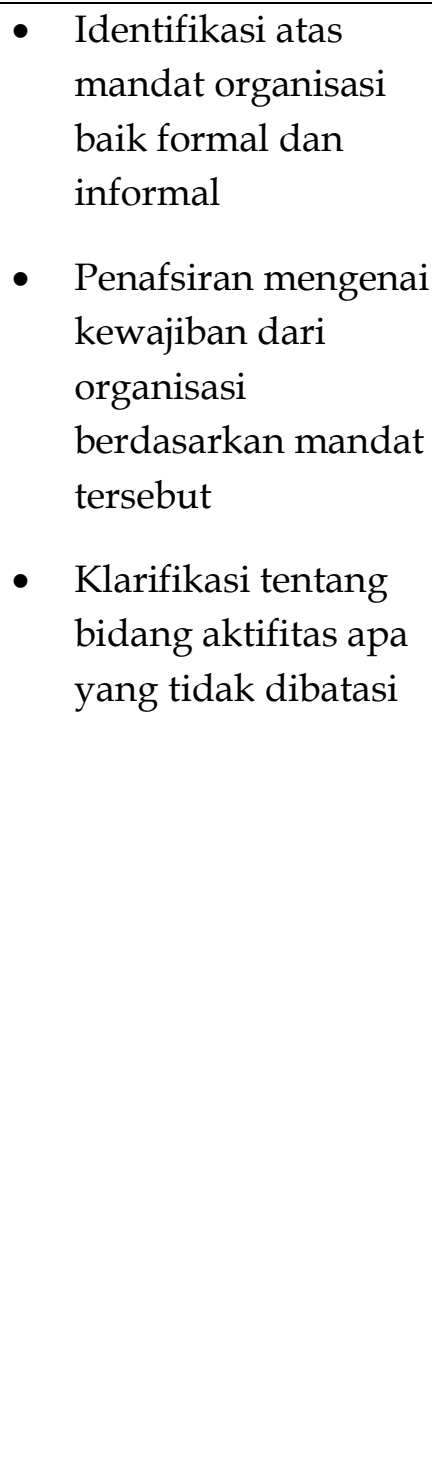 & $\begin{array}{l}\text { - Sejalan dengan misi } \\
\text { pembangunan daerah } \\
\text { khususnya pelayanan } \\
\text { kebencanaan } \\
\text { - Penguatan struktur } \\
\text { (infrastruktur) } \\
\text { kebencanaan untuk } \\
\text { mempercepat } \\
\text { pemulihan pasca } \\
\text { bencana. } \\
\text { Penanggulangan } \\
\text { bencana meliputi } \\
\text { kesadaran dan } \\
\text { kesiapan, } \\
\text { penanganan tanggap } \\
\text { darurat dan pasca } \\
\text { bencana baik } \\
\text { pemerintah dan } \\
\text { masyarakat. selain } \\
\text { itu, Pengurangan } \\
\text { resiko bencana dan } \\
\text { reformasi birokrasi } \\
\text { internal organisasi } \\
\text { merupakan aktifitas } \\
\text { dari bidang BPBD } \\
\text { Kabupaten } \\
\text { Banyuwangi. }\end{array}$ \\
\hline $\begin{array}{ll}\text { 3. } & \text { Memperjelas Misi } \\
& \text { Organisasi dan Nilai }\end{array}$ & 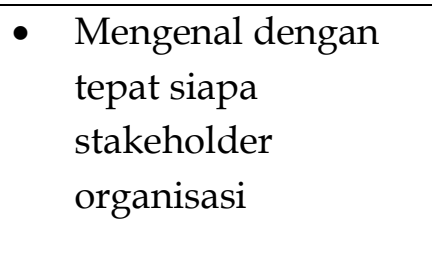 & $\begin{array}{l}\text { Peran stakeholder } \\
\text { dari pemerintah baik } \\
\text { pusat dan daerah, } \\
\text { swasta, dan } \\
\text { masyarakat melalui }\end{array}$ \\
\hline
\end{tabular}




\begin{tabular}{|c|c|c|}
\hline Tahapan bryson & Indikator & Evaluasi Renstra BPBD \\
\hline & $\begin{array}{l}\text { - Kekhususan masing- } \\
\text { masing stakeholder } \\
\text { untuk menentukan } \\
\text { apa yang dibutuhkan } \\
\text { dari kinerja } \\
\text { organisasi } \\
\text { - Membuat suatu } \\
\text { keputusan tentang } \\
\text { bagaimana kinerja } \\
\text { organisasi dapat } \\
\text { mengikuti kriteria } \\
\text { kebutuhan } \\
\text { stakeholder }\end{array}$ & $\begin{array}{l}\text { desa tanggung } \\
\text { bencana } \\
\text { BPBD selaku } \\
\text { pembuat arah strategi } \\
\text { dan kebijakan } \\
\text { penanggulangan } \\
\text { bencana. Swasta dan } \\
\text { masyarakat } \\
\text { membantu dalam } \\
\text { pelaksanaan } \\
\text { penanggulangan } \\
\text { bencana yang efektif. } \\
\text { BPBD melibatkan } \\
\text { masyarakat pada } \\
\text { desa tangguh } \\
\text { bencana dan } \\
\text { berkoordinasi antar } \\
\text { instansi secara } \\
\text { vertikal dan } \\
\text { horizontal. Selain itu } \\
\text { BPBD membuat } \\
\text { strategi } \\
\text { penanggulangan } \\
\text { bencana yang } \\
\text { dijadikan pedoman } \\
\text { penanggulangan } \\
\text { bencana di daerah }\end{array}$ \\
\hline $\begin{array}{l}\text { 4. Menilai Lingkungan } \\
\text { Eksternal dan Internal }\end{array}$ & $\begin{array}{ll}\text { - } & \text { Strength } \\
\text { - } & \text { Weakness } \\
\text { - } & \text { Opportunities } \\
\text { - Challenge }\end{array}$ & 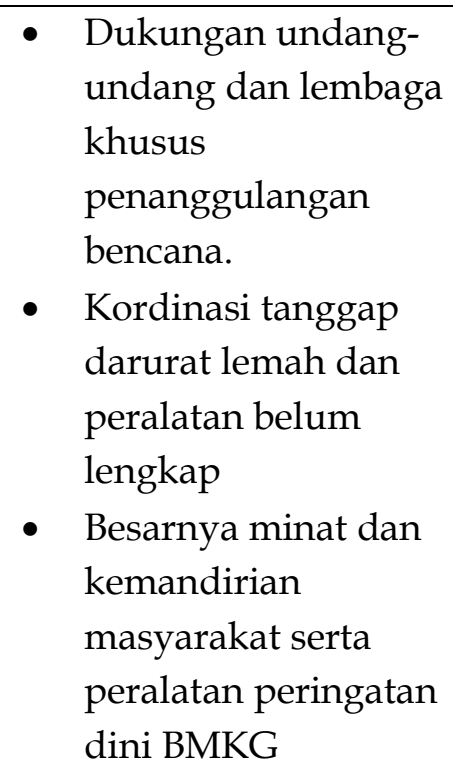 \\
\hline
\end{tabular}




\begin{tabular}{|c|c|c|}
\hline Tahapan bryson & Indikator & Evaluasi Renstra BPBD \\
\hline & & $\begin{array}{l}\text { - Terjadinya } \\
\text { Perubahan undang- } \\
\text { undang, perubahan } \\
\text { cuaca ekstrim dan } \\
\text { pengabaian terhadan } \\
\text { ancaman bencana } \\
\text { alam. }\end{array}$ \\
\hline $\begin{array}{l}\text { 5. } \text { Identifikasi Isu } \\
\text { Strategis yang dihadapi } \\
\text { Organisasi }\end{array}$ & Analisis isu-isu strategis & $\begin{array}{l}\text { Koordinasi sulit dengan } \\
\text { kementrian dan } \\
\text { pemerintah provinsi } \\
\text { pada tahap tanggap } \\
\text { darurat serta kekurangan } \\
\text { tenaga ahli untuk update } \\
\text { data kebencanaan } \\
\text { kepada BPBD Provinsi } \\
\text { dan BNPB. }\end{array}$ \\
\hline $\begin{array}{l}\text { 6. Merumuskan Strategi } \\
\text { untuk Mengelola Isu }\end{array}$ & $\begin{array}{l}\text { Strategi untuk mengatasi } \\
\text { isu-isu strategis }\end{array}$ & $\begin{array}{l}\text { Optimalisasi Manajemen } \\
\text { organisasi serta } \\
\text { penguatan tugas dan } \\
\text { fungsi penanggulangan } \\
\text { bencana secara } \\
\text { komprehensif. }\end{array}$ \\
\hline $\begin{array}{l}\text { 7. Ulasan dan } \\
\text { Mengadopsi Strategi } \\
\text { atau Rencana Strategis }\end{array}$ & $\begin{array}{l}\text { Mereview dan } \\
\text { menyetujui strategi dan } \\
\text { rencana }\end{array}$ & $\begin{array}{l}\text { - BPBD Kabupaten } \\
\text { Banyuwangi sesuai } \\
\text { UU } 242007 \\
\text { penanggulangan } \\
\text { bencana } \\
\text { - membuat rencana } \\
\text { stretegis berpedoman } \\
\text { pada RPJMD } \\
\text { Kabupaten } \\
\text { Banyuwangi }\end{array}$ \\
\hline $\begin{array}{l}\text { 8. Membentuk Visi } \\
\text { Organisasi yang Efektif }\end{array}$ & $\begin{array}{l}\text { Menyusun visi } \\
\text { organisasi }\end{array}$ & $\begin{array}{l}\text { Terwujudnya } \\
\text { Masyarakat Banyuwangi } \\
\text { yang semakin sejahtera, } \\
\text { mandiri dan berakhlak } \\
\text { mulia melalui } \\
\text { peningkatan } \\
\text { perekonomian dan } \\
\text { kualitas sumberdaya } \\
\text { manusia. Visi tersebut } \\
\text { sesuai dengan visi kepala }\end{array}$ \\
\hline
\end{tabular}




\begin{tabular}{|c|c|c|}
\hline Tahapan bryson & Indikator & $\begin{array}{l}\text { Evaluasi Renstra BPBD } \\
\text { daerah terpilih } \\
\text { kabupaten banyuwangi. }\end{array}$ \\
\hline $\begin{array}{l}\text { 9. } \text { Mengembangkan } \\
\text { Proses Implementasi } \\
\text { Efektif }\end{array}$ & $\begin{array}{l}\text { - } \begin{array}{l}\text { Peranan } \\
\text { implementsai dan } \\
\text { tanggungjawab } \\
\text { anggota }\end{array} \\
\text { - } \text { Sasaran khusus } \\
\text { - Langkah } \\
\text { penanganan } \\
\text { - Penyusunan } \\
\text { jadwal } \\
\text { - Sumber daya } \\
\text { yang diperlukan } \\
\text { Proses } \\
\text { komunikasi } \\
\text { Proses review, } \\
\text { monitoring dan } \\
\text { prosedur koreksi } \\
\text { Prosedur } \\
\text { pertanggung } \\
\text { jawaban }\end{array}$ & $\begin{array}{l}\text { Peranan implementasi } \\
\text { yaitu BPBD bertugas } \\
\text { menyusun rencana } \\
\text { berupa dokumen, } \\
\text { monitoring dan } \\
\text { mengendalikan } \\
\text { kebijakan pemerintah } \\
\text { tentang } \\
\text { penanggulangan } \\
\text { bencana. } \\
\text { Sasaran khusus dibuat } \\
\text { untuk strategi } \\
\text { penanggulangan } \\
\text { bencana kabupaten } \\
\text { banyuwangi } \\
\text { Langkah penanganan } \\
\text { dan Prosedur } \\
\text { tangungjawab dimuat } \\
\text { dalam struktur } \\
\text { organisasi. Namun } \\
\text { monitoring tidak } \\
\text { dicantumkan. } \\
\text { penyusunan jadwal } \\
\text { yang sistematis tidak } \\
\text { dicamtumkan secara } \\
\text { eksplisit } \\
\text { sumber daya } \\
\text { organisasi sudah } \\
\text { tergambar dalam } \\
\text { renstra BPBD } \\
\text { Kabupaten } \\
\text { Banyuwangi. Namun } \\
\text { komunikasi untuk } \\
\text { menyampaikan pesan } \\
\text { bencana dari BMKG. }\end{array}$ \\
\hline
\end{tabular}




\begin{tabular}{|c|c|c|}
\hline Tahapan bryson & Indikator & Evaluasi Renstra BPBD \\
\hline $\begin{array}{l}\text { 10. menilai kembali } \\
\text { Strategi dan Proses } \\
\text { Perencanaan Strategis }\end{array}$ & $\begin{array}{l}\text { Evaluasi untuk di masa } \\
\text { depan }\end{array}$ & $\begin{array}{l}\text { Evaluasi di masa depan } \\
\text { dapat dilakukan dengan } \\
\text { melihat proses tanggap } \\
\text { darurat bencana alam di } \\
\text { daerah untuk dijadikan } \\
\text { perbaikan dari aspek pra } \\
\text { bencana agar mampu } \\
\text { meminimalisir dampak } \\
\text { bencana alam. Hal ini } \\
\text { menyesuaikan dengan } \\
\text { rencana strategis BNPB, } \\
\text { BPBD Provinsi Jawa } \\
\text { Timur. }\end{array}$ \\
\hline
\end{tabular}

Sumber: Hasil Olahan

Sepuluh langkah sesuai tahapan dari Bryson dapat diketahui bahwa proses inisiasi pada awal rencana strategis sesuai dengan tugas khusus dari organisasi yaitu menyusun dokumen perencanaan untuk dijadikan pedoman pemerintah daerah dalam penanggulangan bencana. kesesuaian tersebut ditunjang dengan kebutuhan organisasi terkait sumberdaya manusia namun tidak mencantumkan besarnya anggaran yang berasal dari Anggaran Pendapatan dan Belanja Daerah. Mandat orgnaisasi dimulai dengan visi kepala daerah dimana BPBD ini tidak secara khusus mencantumkan visi organisasi sehingga visi yang digunakan merupakan visi dari kepala daerah terpilih.

Pendekatan vision of succes ini merupakan pendekatan yang membedakan dengan pendekatan perencanaan strategis pada umumnya yang digunakan oleh lembaga pemerintahan. Adapaun pendekatan yang dimaksud yaitu pendekatan langsung. Sebenarnya renstra BPBD Kabupaten Banyuwangi masih menggunakan pendekatan langsung dengan mereview mandat yang berasal dari hierarki peraturan perundang-undangan kemudian dirumuskan analisis kekuatan, kelemahan, peluang dan tentangan. Dengan pendekatan vision of succes ini mampu melihat keselarasan strategi yang dibuat oleh organisasi dengan visi yang dirumuskan terlebih dahulu.

Analisis isu strategis melalui SWOC dibuat berdasarkan telaah lingkungan internal dan eksternal dari organisasi untuk mendapatkan strategi dalam mengelola isu. Strategi utama tersebut diperoleh dari kekuatan dan peluang yang dimiliki oleh organisasi yang disesuaikan dengan Undang-undang penanggulangan bencana dan rencana pembangunan jangka menengah Kabupaten Banyuwangi. Proses implementasi dari rencana strategis belum mampu secara efektif dilakukan karena tidak terdapat penjadwalan dan proses monitoring selama strategi tersebut dilaksanakan.

\section{PENUTUP}

BPBD Kabupaten Banyuwangi merupakan organisasi di tingkat daerah yang secara khusus dibentuk untuk mengurusi masalah-masalah kebencanaan dengan menyusun pedoman perencanaan penanggulangan bencana alam melalui dokumen rencana strategis. Dokumen 
tersebut dijadikan pedoman untuk menyusun kebijakan berisi strategi yang disusun berdasarkan analisis lingkungan internal dan lingkungan eksternal untuk memperoleh strategi yang tepat. Namun strategi yang demikian merupakan pendekatan langsung yang mayoritas digunakan oleh pemerintah. Oleh karena itu pendekatan vision of success bermaksud mengidentifikasi dari aspek lain yaitu melalui penjabaran visi kepala daerah terpilih kabupaten banyuwangi.

Visi yang telah ditetapkan oleh bupati terpilih diadopsi oleh BPBD Kabupaten Banyuwangi dalam merumuskan strategi penanggulangan bencana. Strategi tersebut disesuaikan dengan visi dari rencana pembangunan jangka menengah nasional serta RPJMD Kabupaten Banyuwangi. Keselarasan visi tersebut penting agar stretegi yang dirumuskan searah dengan hierarki organisasi di atasnya. Sementara itu, evaluasi tahapan implementasi pada renstra tersebut masih ditemukan beberapa hal diantaranya tidak adanya monitoring pada strategi yang telah dirumuskan serta belum adanya jadwal yang sistematis terkati strategi penanggulangan bencana alam.

Penyusunan rencana strategis oleh BPBD Kabupaten Banyuwangi merupakan salah satu upaya pemerintah daerah dalam penangangan bencana alam melalui penyusunan strategi penanganan. Dengan dijadikannya pedoman kebijakan penanggulangan bencana oleh pemerintah hendaknya telah disusun pula rincian jadwal terhadap pelaksanaan strategi sehingga strategi tersebut lebih terjadwal ketika diimplementasikan. Saran selanjutnya yaitu merumuskan kembali visi organisasi yang dicantumkan pada rencana strategis BPBD Kabupaten Banyuwangi. Tentunya visi yang dirumuskan organisasi selaras dengan visi dari kepada daerah terpilih.

\section{DAFTAR PUSTAKA}

Badan Nasional Penanggulangan Bencana. Rencana strategis Badan Nasional (2015). Penanggulangan Bencana tahun 2015-2019.

(2016). Risiko Bencana Indonesia. Deputi Bidang Pencegahan dan Kesiapsiagaan. Jakarta, Badan penanggulangan bencana nasional

(2017). Potensi dan Ancaman Bencana. 9 Mei. Retrieved from

https://www.bnpb.go.id/home/pot ensi.html pada .

Badan Perencanaan Pembangunan Nasional. (2014). Peraturan Presiden Nomor 2 Tahun 2015 Tentang Rencana Pembangunan Jangka Menengah Nasional 2015-2019.

Bryson, J., M. (2004). Strategic planning for public and nonprofit organizations : a guide to strengthening and sustaining organizational achievement. USA,: Jossey-Bass.

Bryson, J., M. (2010). The Future of Public and Nonprofi t Strategic Planning in the United States. 15 Mei 2019. Public Administration Review, 255-267. retrieved from,https:/ / pdfs.semanticscholar.o rg/7bf5/bf15b7eb779b3e09bbb0ac4d 2d5a71843726.pdf .

Danar, O., R. (2016). Building Community Resilience in Tsunami Risk Area: Evidence from Pancer Hamlet, Banyuwangi District, Indonesia. Tohoku University.

Nilamsari, N. (2014). Memahami Studi Dokumen dalam Penelitian 
Kualitatif. Wacana Volume XIII (2) 177-181.

Pemerintah Kabupaten Banyuwangi. (2012). Peraturan Daerah Nomor 8 Tahun 2012 Tentang Rencana Tata Ruang Wilayah Kabupaten Banyuwangi Tahun 2012-2032.

Pemerintah Kabupaten Banyuwangi. (2016). Rencana Strategis 2016-2021 Badan Penanggulangan Bencana Daerah Kabupaten Banyuwangi.

Pramono, I.,B. dan Savitri, E. (2018). Analisis Banjir Bandang di DAS Glondong, Banyuwangi Suatu pembelajaran dari perhitungan kerugian. Seminar Nasional Geomatika 2018: Penggunaan dan Pengembangan Produk Informasi Geospasial Mendukung Daya Saing Nasional hal. 1129-1136.

Rezvani, M., Gilaninia, S., and Mousavian, S., J. (2011). Strategic Planning: A Tool For Managing Organizations In Competitive Environments. Australian Journal of Basic and Applied Sciences, 5(9): 1537-1546.

Saksono. (2018). Kerugian Banjir Ditaksir Rp 5 M. 10 Mei 2019. Retrieved from https:/ / radarbanyuwangi.jawapos.c om/read/2018/06/26/82999/kerugi an-banjir-ditaksir-rp-5-m.

World bank. (2001). STRATEGIC PLANNING: A TEN-STEP GUIDE. 15 Mei 2019. Retrieved from https://siteresources.worldbank.org /INTAFRREGTOPTEIA/Resources/ mosaica_10_steps.pdf 